\title{
Léonard, Sarah and Christian Kaunert. 2019. Refugees, security and the European Union. London: Routledge. 220 p.
}

doi: http://dx.doi.org/10.18543/djhr.1901

Over the last two decades, the securitization of borders and human mobility has become a more "high profile" issue in academia. The general consensus is that in Western countries policies on migration have been increasingly adopted through security concerns. Such a statement brings together a broad and complex set of issues: migration, asylum, cross border crimes, external and internal security, to mention some of them. Therefore, in this book, Léonard and Kaunert recognize the need to refine the analysis and undertake the arduous task of decoding the realm and functioning of the securitization process on the specific area of asylum policy in the European Union (EU).

"To what extent and in what ways have asylum-seekers and refugees been securitized in the EU?" (p. 8) is the over-arching research question that the book answers. With this purpose, the authors develop an exhaustive and systematic study, with deep scientific and methodical rigor, to shed light on the aforementioned complex set of policies, which nowadays is key to examine the present and the possible future of the European integration process.

The analysis is carried out according to the principle of methodological triangulation (multiple methodologies) for data collection: 1) an exhaustive review of the secondary literature on the topic; 2) documentary analysis: official documents published by the EU institutions, documents pertaining to the scrutiny of EU policies by national parliaments (in particular, UK House of Lords and House of Commons), documents emanating from intergovernmental organizations (IGOs) and non-governmental organizations (NGOs) active in the field of asylum and migration (press releases, reports, newsletters), newspapers articles and news websites; 3 ) semi-structured interviews of the elites involved in the EU decision-shaping and decision making processes: 108 people in total, including officials from the EU institutions and the Permanent Representations of the Member States (MS) to the EU, officials from the national ministries of the EU MS, scholars and representatives of various NGOs, lobbies and IGOs (the United Nations High Commissioner for Refugees and the International Organization for Migration).

The research theoretical framework is based on the securitization theory developed by "the Copenhagen School", as a reference approach 
for analysing the linkages between migration flows and security. In this sense, the Copenhagen School emphasizes the process of linguistic construction of security issues. In other words, this theory argues that "the 'security-ness' of an entity does not depend on objective features, but rather stems from the interactions between a securitizing actor and its audience" (Balzacq et al. 2016, 496). According to this analytical framework, the securitization process operates through speech acts that justifies the adoption of emergency and extraordinary measures to combat the perceived security threat.

The book contrasts the Copenhagen School securitization theory in regard with the political and legal realm of asylum in the EU, in order to determine whether there are sufficient elements to affirm that asylum seekers and refugees are treated as "security threats" and, consequently, if they have been subject to a securitization process. Thus, Chapter 1 examines the securitization theory of the Copenhagen School detailing its main points. Subsequently, the research identifies the limitations of the Copenhagen framework when addressing current security policies, insofar as: 1) it adopts a restricted concept of security, regarding its traditional political-military sense; 2 ) it focuses exclusively on the securitization speech acts, without taking into consideration the practices, as suggested by Bigo (2002) and the so-called "Paris School" (Wæver 2004; C.A.S.E. Collective 2006); 3) it assumes that security policies always operate through exceptional and extraordinary emergency measures in its strict meaning.

Regarding those limitations, the authors warn of the need for a broader framework to analyse the policies of the EU, as an international sui generis organization, strongly technocratic, with a discourse respectful of the rule of law. Thus, the book develops a new securitization framework grounded on four new ideas and proposals: 1) expanding the concept of security; 2) recognizing securitization processes through practices and through association, in addition to speech acts; 3) analysing the context of securitizing moves - in both its historical and institutional dimensions-; and 4) understanding extraordinary and exceptional measures in a broader sense. As a result, this new securitization framework is one of the most important contributions of the book, which increases the analytical purchase of the securitization theory.

Chapters 2 and 3 carry out a detailed review of the milestones in the development of migration and asylum policies in the EU, from a historical and institutional point of view. The analysis in both chapters is carried out distinguishing between migration and asylum, which provides another of the fundamental contributions of the research. Léonard and Kaunert point out the significant differences of these two 
policies, which are usually approached together in ambiguous ways. In this sense, the book highlights the importance of a special approach to securitization of asylum seekers and refugees, taking into account the particularities of asylum law.

Chapter 2 analyses the historical context in Europe before the EU received competences on immigration and asylum matters. In particular, the authors wonder if migration and asylum policies had been securitized prior to the attribution of competences to the European institutions through the Maastricht Treaty in 1993. For this purpose, they explore the fields of cooperation deployed by States at the international level (League of Nations, United Nations), European level (Council of Europe), and intergovernmental level through the cooperation among MS in "ad hoc" groups outside the European Community framework. The chapter concludes that migrants, asylum seekers and refugees were not treated under the securitization paradigm before 1993, despite the fact that there was already a trend of restrictive policies especially from the 1970s onwards.

Chapter 3 examines the institutional context of asylum, migration and border policies since the EU acquired competences on these issues in 1993. It studies its evolution through the Maastricht Treaty (1993), the Amsterdam Treaty (2001) and the Lisbon Treaty (2007). The analysis reflects the "communitarization" process, meaning the progressive transfer of powers from the MS and the European Council to the other EU institutions (the European Commission, the European Parliament, and the European Court of Justice -ECJ-). The authors emphasize the significance of this process of transfer of competencies to institutions that have generally showed themselves to be more "refugee-friendly" (p. 73) than the Council of Ministers, providing an environment less conductive to the success of attempts at securitizing asylum-seekers and refugees.

Along with the "communitarization" process, the authors identify the "judicialization" of asylum policy, broadly defined as the increasing influence of legal texts and actors on asylum policy-making. In this sense, the competences acquired by the ECJ, the indirect influence of the jurisprudence of the European Court of Human Rights (with jurisdiction over all EU MS), the need to comply with the 1951 Geneva Convention established on the successive European treaties, and the inclusion of the Charter of Fundamental Rights as primary law on the Lisbon Treaty. Thus, the book concludes that the "judicialization" process has rendered the EU asylum policy a more liberal field and thereby less amenable to successful securitizing moves.

According to the importance of distinguishing asylum from migration policies, Chapter 4 analyses the evolution of the "Common 
European Asylum System" (CEAS), since its beginning in 1999. After studying the three phases of development of the CEAS (the third still in progress), the book argues that the development of the EU common asylum policy has not been driven by security concerns, contrary to a large part of the literature. Indeed, the research finds that the involvement of the EU in asylum matters has actually led to a consolidation and codification of the rights of asylum-seekers and refugees across the EU. In particular, the establishment of minimum standards and the installation of specialized agencies (i.e., the European Asylum Support Office -EASO-) can be seen as positive contributions. MS are now obliged to comply with them, from which they cannot derogate without exposing themselves to an infringement procedure launched by the European Commission.

Thus, these four chapters reach the first conclusion of the study: from the perspective of the Copenhagen School, there are no clear and solid elements to argue the securitization of asylum. There are no speech acts found in the rhetoric of the EU institutions and MS. Even, on the contrary, the processes of "communitarization" and "judicialization" in the EU have produced an improvement in the rights of asylum seekers and refugees. In addition, they have created a procedural system that guarantees higher standards of protection and burdens to the discretion of those MS reluctant to receive migratory flows.

However, if we take into account the criticism to the Copenhagen School framework, this first conclusion is not enough to answer the research question. The non-existence of speech acts does not mean that there is no securitization in the field of asylum, but rather that it is not within the narrow margins delineated by the traditional theoretical framework. For this reason, Chapters 5 and 6 examine the EU policies on irregular migration and terrorism, areas closely related to asylum and in which there is a clear link with security issues. Consequently, the following question is whether the securitization of irregular migration and terrorism have moved into the asylum system.

In this sense, Chapters 5 and 6 verify the process of "securitization by association" in light of the new securitization framework developed by the book. Chapter 5 focuses on the analysis of external border control policies and, in particular, those referring to irregular migration. The research determines the impact of these policies on people who intend to arrive at the external borders of the EU seeking for asylum, highlighting the obstacles and the few access routes to the asylum system. The "cayuco crisis" occurred in 2005-2006 in the Canary Islands, southern border of Spain, is analysed as an empirical case. In this regard, it was the first "migration crisis" faced by the EU, which 
provided assistance to Spain through joint operations coordinated by the then recently established European Agency for the Management of Operation Cooperation at the External Borders of the Member States (Frontex). The response to this "migration crisis" is considered the beginning of the securitization of irregular migration through practices at the EU. In addition, this process has indirectly resulted in the securitization of asylum-seekers and refugees due to their association with irregular migration. Finally, the chapter provides one of the most interesting reflections of the book, regarding the existence of a major paradox in EU policy towards asylum seekers and refugees: "whilst the EU's action has led to the steady improvement of asylum standards across the MS, gaining the access to those has become increasingly difficult for asylum seekers" (p. 158).

Chapter 6 focuses on the collective securitization of terrorism in the EU after 9/11, based on a previous research work of the authors (Kaunert and Léonard 2019). In this context, the book carries out an exhaustive analysis on the evolution of the perception at the EU and the majority of the MS regarding the links between asylum seekers, refugees and terrorism. 2015 is considered a pivotal year in the turn towards the association of asylum with terrorist acts. In order to assess the period prior to 2015, the chapter takes as empirical case of analysis the very contentious proposal presented by the British government to extra-territorialise the processing of asylum applications. This proposal was informed by security concerns in the domestic context due to the prominent role of the UK in the "War on Terror". However, at the EU level, the book shows how the opposition of the European Commission and some MS played a key role in decoupling asylum from terrorism.

Notwithstanding, from 2015 onwards, a change was evidenced on the responses to two major EU "crises" linked to human mobility. On the one hand, the "migratory crisis", caused by the increased arrival of refugees and migrants across the Mediterranean Sea or overland through Southeast Europe. On the other hand, the "terrorism crisis", triggered by several major terrorist attacks in different MS (Belgium, France, Germany, Spain and the UK). The authors argue that the juxtaposition of both crises provided a fertile environment to link asylum to terrorism, thereby securitizing asylum-seekers and refugees through an association made with terrorists. This facilitated a more securitized policy agenda, as observed in the European Agenda on Migration launched by the European Commission (2015), the founding of the hotspots approach, and the establishment of a European Border and Cost Guard Agency (as a reformed Frontex Agency) in September 
2016. In this sense, the authors note a trend from securitization through practices or through association to militarization.

In conclusion, the research findings provide an in-depth contribution to the academic literature on migration and asylum, to the securitization theory and, in particular, to the literature on the securitization of asylum-seekers and refugees in the EU, as well to the literature on European integration. Indeed, the book highlights the importance of making a precise distinction between migration and asylum, and the need to consider the particularities of the latter as a human right. Furthermore, the authors provide an amended theoretical framework on securitization, pointing out new ideas into the traditional theory when analysing whether a certain area of reality is being constructed as a threat to security. In addition, the refinement of the securitization theory leads to a more nuanced and sophisticated understanding of how the links between security and the specific field of asylum operate. In this sense, the new ideas provided by the amended securitization framework becomes increasingly necessary nowadays, in order to reach an improved comprehension of asylum and migration policies. For example, the new framework is a valuable input to analyse the securitization approach at the New Pact on Migration and Asylum launched by the European Commission (2020), or the restrictions on border policies and asylum procedures due to the COVID crisis (EASO 2020; McAdam 2020). At last, all these contributions fall on a set of policies that are key today for the development of the European integration process and the best resolution of the tensions inherent in the debates between freedom and security that are at stake.

\section{References}

Balzacq, Thierry, Sarah Léonard and Jan Ruzicka. 2016. "'Securitization' revisited: theory and cases». International Relations, 30(4): 494-531.

Bigo, Didier. 2002. "Security and Immigration: Toward a critique of governmentality of unease», Alternatives, 27 (special issue): 63-92.

C.A.S.E. Collective. 2006. "Critical approaches to security in Europe. A network manifesto», Security Dialogue, 37(4): 443-487.

European Asylum Support Office. 2020. COVID-19 emergency measures in asylum and reception systems, 2, July 15, EASO. Acceded October 15, 2020: https://www.easo.europa.eu/sites/default/files/publications/covid19emergency-measures-asylum-reception-systems-issue-2.pdf

European Commission. 2015. "A European Agenda on Migration», COM(2015) 240 final, 13 May 2015. Brussels: European Commission. 
European Commission. 2020. "Communication from the Commission to the European Parliament, the Council, the European Economic and Social Committee and the Committee of the Regions on a New Pact on Migration

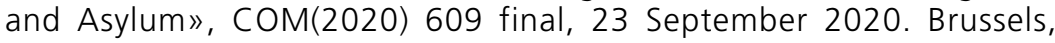
European Commission.

Kaunert, Christian, and Sarah Léonard. 2019. «The collective securitization of terrorism in the European Union», West European Politics, 42(2): 261-277.

McAdam, Jane. 2020. "A watching brief on the impacts of COVID-19 on the world's displaced people». International Journal of Refugee Law, 32(2): 364-366.

Wæver, Ole. 2004. «Aberystwyth, Paris, Copenhagen. New 'Schools' in Security Theory and their origins between core and periphery», paper presented at the 45th Annual Convention of the International Studies Association, Montreal, Canada, 17-20 March.

Gustavo de la Orden Bosch University of Deusto 


\section{Copyright}

Deusto Journal of Human Rights / Revista Deusto de Derechos Humanos is an Open Access journal; which means that it is free for full and immediate access, reading, search, download, distribution, and reuse in any medium only for non-commercial purposes and in accordance with any applicable copyright legislation, without prior permission from the copyright holder (University of Deusto) or the author; provided the original work and publication source are properly cited (Issue number, year, pages and DOI if applicable) and any changes to the original are clearly indicated. Any other use of its content in any medium or format, now known or developed in the future, requires prior written permission of the copyright holder.

\section{Derechos de autoría}

Deusto Journal of Human Rights / Revista Deusto de Derechos Humanos es una revista de Acceso Abierto; lo que significa que es de libre acceso en su integridad inmediatamente después de la publicación de cada número. Se permite su lectura, la búsqueda, descarga, distribución y reutilización en cualquier tipo de soporte sólo para fines no comerciales y según lo previsto por la ley; sin la previa autorización de la Editorial (Universidad de Deusto) o la persona autora, siempre que la obra original sea debidamente citada (número, año, páginas y DOI si procede) y cualquier cambio en el original esté claramente indicado. Cualquier otro uso de su contenido en cualquier medio o formato, ahora conocido o desarrollado en el futuro, requiere el permiso previo por escrito de la persona titular de los derechos de autoría. 